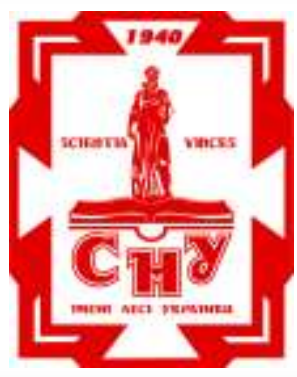

Науковий вісник Східноєвропейського національного університету

імені Лесі Украӥнки

Розділ III. Фізіологія

людини і тварин

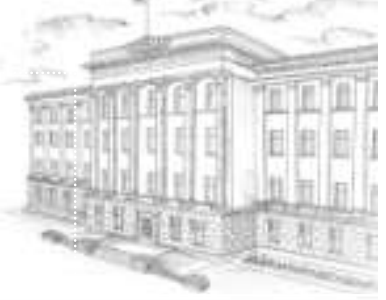

Серія: Біологічні науки, 2020, 1 (389)

УДК 616.31-089:616.6:611-018.4:615.21:616-092.9＜noBreak> DOI https://doi.org/10.29038/2617-4723-2020-1-389-72-79

\title{
Mandible Aseptic Osteonecrosis Caused by admission of the Narcotic Substances Containing Amino phosphonic Impurities: Levelling with Trilon B
}

\section{Semen Mostovoy ${ }^{1}$, Vasil Pikaluk²，Khrystyna Plekhanova ${ }^{3}$ ，Genadiy Tkach ${ }^{5}$, Maxim Peshkov ${ }^{4}$}

${ }^{1}$ Medical Academy named after S. I. Georgievsky, Simferopol, Ukraine

${ }^{2}$ Lesya Ukrainka Eastern-European National University, Lutsk, Ukraine

${ }^{3}$ The Lithuanian University of Health Sciences, Kaunas, Lithuania

${ }^{4}$ Pathoanatomical bureau, Taganrog, Russia

${ }^{5}$ Department of Morphology, Medical Institute, Sumy State University, Sumy, Ukraine

Address for correspondence: Semen-34@yandex.ru, Khrystyna.plekhanova@gmail.com

\begin{abstract}
The aim of our study was to correct osteosclerotic changes (aseptic bone necrotic lesion) of mandibular bones in laboratory white rats. Changes were caused by 1 and 3 monthly intragastric administration of amino phosphonic impurity. It was formed during artisanal manufacture of meta-amphetamine. A dose was $63 \mathrm{mg} / \mathrm{kg} 1$ time per day, and followed by exposure to $5 \%$ water solution of Trilon B at a dose of $250 \mathrm{mg} / \mathrm{kg}$. Mandible structure was researched by light microscopy. Three additional functional indices and elements of node-strut analysis were enrolled. Indices and their abbreviations were used in accordance to Committee on Histomorphometry Nomenclature (ASBMR).

It was found that intragastric administration of Trilon B at a dose of $250 \mathrm{mg} / \mathrm{kg}$ after one-month- and three-month influence of amino phosphonic impurity (by-product of methamphetamine artisanal synthesis) at a dose of $63 \mathrm{mg} / \mathrm{kg} \mathrm{led} \mathrm{to}$ improvement of mandible bone remodeling. Also, enhancement of processes that removed osteosclerotic changes as well as an involution of myelofibrosis took place.
\end{abstract}

Keywords: artisanal production of methamphetamine, involution, mandible, bone necrosis, Trilon B.

\section{Нівелювання явищ асептичного остеонекрозу нижньощелепної кістки, викликаного прийомом наркотичних речовин, які містять амінофосфонові домішки, за допомогою Трилону Б в експерименті}

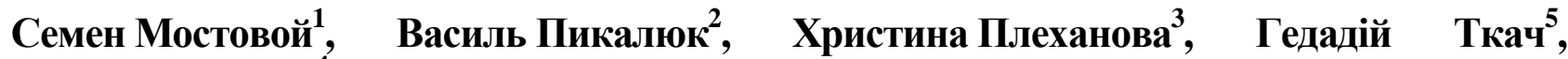 Максим Пешков $^{4}$}

\footnotetext{
${ }^{1}$ Кримська медична академія імені С. І. Георгієвського, Сімферополь, Україна

${ }^{2}$ Східноєвропейський національний університет імені Лесі Українки, Луцьк, Україна

${ }^{3}$ The Lithuanian University of Health Sciences, Каунас, Литва

${ }^{4}$ Муніципальна бюджетна установа охорони здоров'я «Патологоанатомічне бюро», Таганрог, Росія

${ }^{5}$ Медичний інститут Сумського державного університету, Суми, Україна
}

Резюме. Метою дослідження була корекція остеосклеротичних змін (вид асептичних остеонекротичних уражень) в нижньощелепних кістках лабораторних білих щурів, викликаних 1 i 3-місячним внутрішньошлунковим уведенням амінофосфонової домішки, яка утворюється при кустарному виготовленні 
метаамфітаміну дозою 63 мг/кг 1 раз на добу, з подальшим впливом 5\% водного розчину трилону Б дозою 250 мг/кг. За допомогою світлової мікроскопії досліджувався структурний стан нижньощелепної кістки, із застосуванням node-strut аналізу і використанням показників та абревіатур, запропонованих комітетом із гістоморфометричної номенклатури Американського товариства 3 дослідження кісток і мінералів, а також із включенням трьох додаткових функціональних показників.

Встановлено, що 30-добове введення Трилону Б після 30 і 90-добового впливу досліджуваної амінофосфонової домішки призводило до нормалізації процесів ремоделювання кісткової тканини i, в подальшому, до зменшення, надмірно сформованої та склерозированої кісткової речовини. Викликало процеси інволюції мієлофібротичних змін у кістковомозкових просторах (заміна зон фіброзу ретикулярною стромою 3 клітинами мієлоїдного ряду і рясною васкуляризацією). При коротких термінах впливу досліджуваної амінофосфонової домішки (30 діб) резорбція кісткової тканини здійснювалася за змішаним механізмом із переважанням клітинних механізмів резорбції. При більш тривалому впливі досліджуваної амінофосфонової домішки (90 діб) резорбція кісткової тканини здійснювалася з переважанням неклітинних механізмів, причиною яких стала висока щільність кісткового матриксу з ділянками аваскулярних зон (остеосклеротичні зміни).

Отже, застосування Трилону Б дозою 250 мг / кг у лабораторних білих щурів після 1 і 3-місячного внутрішньошлункового введення амінофосфонової домішки дозою 63 мг / кг призводить до нормалізації процесів ремоделювання кісткової тканини нижньої щелепи 3 активацією резобційних механізмів, які призводять до нівелювання остеосклеротичних змін, інволюції зон мієлофіброзу і відновленням мікроциркуляції ураженого органу.

Ключові слова: підпільне виробництво метамфетаміну, інволюція, нижня щелепа, остеонекроз, Трилон Б.

\section{INTRODUCTION}

Jaw osteonecrosis in drug addicts used artisanal methamphetamine surrogates obtained by processing ephedrine with red phosphorus (has been synthesized by Nagaya Nagayoshi's method) is a disease described more than 15 years ago, and endemic for CIS countries $[1,2,3,4,5,6,7]$. Similar cases were reported in foreign countries' publications [5]. The number of these patients unfortunately does not decrease. Pathogenesis of this disease requires more researches.

We first-ever proved bisphosphonate structure of the studied substance experimentally. We used qualitative and quantitative indices to clarify specific features of jaw structure changes caused by these impurities. That's why we classified it as bisphosphonate-related osteoarthritis $[8,9]$. Hypotheses about pathogenesis of bisphosphonate-associated jaw osteonecrosis did not properly explain the causes and processes of this disease $[10,11,12,13,14]$. We added a lot of information to this disease development theory in our previous studies $[8,9]$. However, our findings were based on trial models and hypothetical.

To date, the optimal conservative treatments for patients with jaw bone necrosis who used artisanal synthesized meta-amphetamine (based on Nagaya Nagayoshi's method) have not been developed. Therefore, the research priority for effective methods of treatment and prevention is still important for this patients' category $[1,2,3,5,6,10]$. That's why a chelating agent Trilon B is a point of interest. This substance is used as an antidote for heavy metal poisoning because it binds calcium for various types of calcifications. Its effectiveness has been confirmed in our experimental study for leveling bone necrotic changes of mandibular bone caused by pamidronic acid [11].
The purpose of the study: osteosclerotic changes correction in the mandibular bones of white outbred rats with chelating agent (Trilon B). Rats were previously exposed to a non-narcotic impurity that was formed during artisanal production of meta-amphetamine and had antiresorptive properties.

\section{MATERIALS AND METHODS}

In the experiment, 40 white outbred male rats weighing 150-200 grams were used. Animals were divided into four equal groups of 10 rats in each group.

The first and the second groups consisted of animals that have been exposed to amino phosphonic impurity administered intragastrically 1 time per day during 30 and 90 days (at a dose of $63 \mathrm{mg} / \mathrm{kg}$ ). This impurity was derived as a result of ephedrine processing with red phosphorus (has been synthesized by Nagai Nagayoshi's method) [8]. The dose was selected according to the oral dose used by drug addicts, which reached $700 \mathrm{mg}$ per day. Species differences in metabolic rates for the human body and laboratory rats were considered $[8,12]$. After a period of exposure for amino phosphonic impurity, animals of both groups received distilled water $1 \mathrm{ml}$ per day intragastrically to equalize experimental conditions. The $3 \mathrm{rd}$ and 4 th groups included animals that also received amino phosphonic impurity intragastrically once a day for 30 and 90 days (at a dose of $63 \mathrm{mg} / \mathrm{kg}$ ). After that, the animals in both groups received Trilon B at a dose of $250 \mathrm{mg} / \mathrm{kg}$ (11) intragastrically once a day for a month [11]. Animals were euthanized with ketamine anesthesia at the rate of $4.4 \mathrm{mg} / \mathrm{kg}$ for 30 and 90 days and decapitated by international rules for experimental animals [13]. The study material was rats' mandibles, fixed for more than 72 hours in $10 \%$ neutral buffered formalin, decalcified in $14 \%$ water solution of Trilon B, and buffered to $\mathrm{pH} 7.0$ with sodium hydroxide. 
Нівелювання явищ асептичного остеонекрозу нижньощелепної кістки, викликаного прийомом наркотичних речовин, які містять амінофосфонові домішки, за допомогою Трилону Б в експерименті

The control of the decalcification endpoint was performed by a gravimetric method [14]. Next, histological processing was performed with isopropanol and mineral oil and paraffin-embedded tissue [15]. Paraffin sections (a thickness was $3 \mu \mathrm{m}$ ) were obtained with Leica RM2245 rotary microtome (Germany) and Surgipath DB80LX blades (USA). Sections were stained with hematoxylin and eosin, Romanowsky - Giemsa, Masson - Goldner, and alcian blue (pH 2.5) with iodic acid and Schiff's reagent (AC + Schiff-reaction). The morphometric study was carried out with a computerized morphometric complex: Olympus CX-31 microscope, Olympus C5050Z digital camera (PRC), and 10x, 20x, 40x, $100 \mathrm{x}$ lenses. Indices and their abbreviations proposed by the American Society of Bone and Mineral Research Histomorphometry Nomenclature Committee (Committee on the Histomorphometry Nomenclature of the American Society for Bone and Mineral Research) were used (15). The parameters for microarchitecture of trabecular bone were determined: the volume of spongy substance (Cn-BV / TV) - $\%$ of bone substance located between the cortical layers. Bone substance condition was also assessed with some parameters: BDS - $\%$ of the surface for necrotized bone substance; OS / BS - osteoid surface; the percentage of the total perimeter for a spongy substance covered with osteoid; OV / BV - osteoid volume; the percentage of spongy substance that has not calcification undergone. Also, N.Oc was determined - the number of osteoclasts in $1 \mathrm{~mm} 2$. As the abbreviations proposed by the American Society of Bone and Mineral Research Histomorphometry Nomenclature Committee included static indices only, we investigated four functional indices to assess physiological processes. OOL (osteocyte osteolysis) - the percentage of bone covered with osteocyte lacunae, also signs of lytic processes took place; FN (fibrinoid necrosis) - the percentage of bone marrow cavity occupied with fibrinoid FBM (bone marrow fibrosis) - the percentage of bone marrow cavity surface prone to fibrosis, and AOS (osteosclerosis area), substances subject to sclerosis. NCR (non-cellular resorption) is the percentage of bone matrix prone to non-cellular resorption [11]. Stellate volume of the bone marrow cavities $\mathrm{V} *$ [17] was determined for a total assessment of the adhesion degree for trabeculae in the spongy substance. Measurements were performed with 30 fields of view for each sample. Statistical processing of the research results was carried out by the methods of parametric statistics, and we used a program STATISTICA 6.0 (Stat Soft, USA) to identify differences between the groups. Arithmetic means value for each index in each group $\overline{\mathrm{X}}$, and its standard error $\mathrm{m} \overline{\mathrm{X}}$ were calculated. The analysis for patterns of normal distribution was performed with Shapiro - Wilk test $(p>0.05)$. The result was positive and the significance of differences was assessed with a parametric Student's t-test. Differences for means in these groups were significant at the level of $\mathrm{p} \leq 0.05$.

Table 1

Histomorphometric indices of lower jaw for laboratory white rats $(\overline{\mathbf{X}} \pm \mathbf{m} \overline{\mathbf{X}})(\overline{\mathbf{X}}$ is the arithmetic mean for sampled index; $m \overline{\mathbf{X}}$ is the standard error for mean sampled value). $N=10$

\begin{tabular}{|c|c|c|c|c|}
\hline & 1 st group & 3 rd group & 2 nd group & 4 th group \\
\hline $\mathrm{Cn}-\mathrm{BV} / \mathrm{TV} \%$ & $75,85 \pm 1,02 \%$ & $64,22 \pm 0,84 \% *$ & $85,59 \pm 0,99 \%$ & $67,74 \pm 1,43 \% * *$ \\
\hline BDS\% & $12,7 \pm 0,13 \%$ & - & $14,37 \pm 0,26$ & - \\
\hline OS/BS \% & $2,28 \pm 0,06 \%$ & - & $2,35 \pm 0,13 \%$ & - \\
\hline $\mathrm{OV} / \mathrm{BV} \%$ & $19,95 \pm 0,34 \%$ & - & $28 \pm 0,12 \%$ & - \\
\hline AOS $\%$ & $3,34 \pm 0,1 \%$ & $2,82 \pm 0,09 \% *$ & $12,16 \pm 0,18 \%$ & $9,06 \pm 0,21 \% * *$ \\
\hline OOL \% & $11,93 \pm 0,23 \%$ & $13,58 \pm 0,5 \%$ * & $17,13 \pm 0,15 \%$ & $7,54 \pm 0,12 \% * *$ \\
\hline FN \% & $8,7 \pm 0,22 \%$ & - & $13,04 \pm 0,32 \%$ & - \\
\hline FBM $\%$ & $5,61 \pm 0,1 \%$ & $3,82 \pm 0,12 \%^{*}$ & $3,52 \pm 0,14 \%$ & $2,37 \pm 0,02 \% * *$ \\
\hline N.Oc ez/MM ${ }^{2}$ & $3,60 \pm 0,33$ & $6,34 \pm 0,14^{*}$ & $3,69 \pm 0,07$ & $4,5 \pm 0,32$ \\
\hline NCR & - & $21,07 \pm 0,57 \%^{*}$ & - & $41,75 \pm 0,61 \% * * *$ \\
\hline $\mathrm{V}^{*} \mathrm{MM}^{3}$ & $\begin{array}{c}0,00342100 \pm \\
0,00012478\end{array}$ & $\begin{array}{c}0,00375260 \pm \\
0,00015351^{*}\end{array}$ & $\begin{array}{r}0,00053201 \pm \\
0,00001140\end{array}$ & $\begin{array}{c}0,00061791 \\
\pm 0,00000581^{* *}\end{array}$ \\
\hline
\end{tabular}

$* \mathrm{p}<0,05$ compared to the first group

** compared to the second group

*** Comparison between 3 and 4 group 


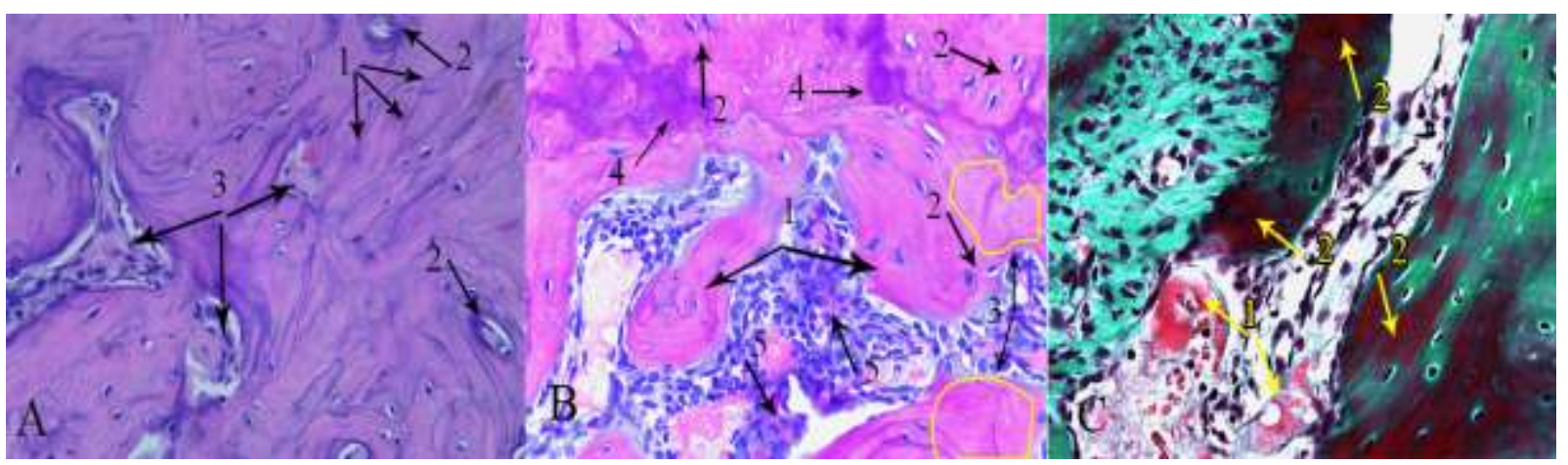

Fig.1 Microstructure of mandibles for animals that exposed to amino phosphonic impurity for 90 days. A. 1. Multiple chaotic cement lines. 2. Reduced volume of medullar spaces. 3. Fibrinoid degeneration. Hematoxylin and eosin staining. Magnification x 400; B. 1. Decoupled bone trabeculae. 2. Hypertrophic osteocytes located in increased lacunae. 3. Areas of osteosclerosis. 4. Basophilia at areas of intensive spot precipitation. Hematoxylin and eosin staining. Magnification x 400; C.1. Extensive perivascular swelling and fibrinoid degeneration of bone marrow. 2. Osteoid mineralization. Masson-Goldner staining. Magnification x 400.

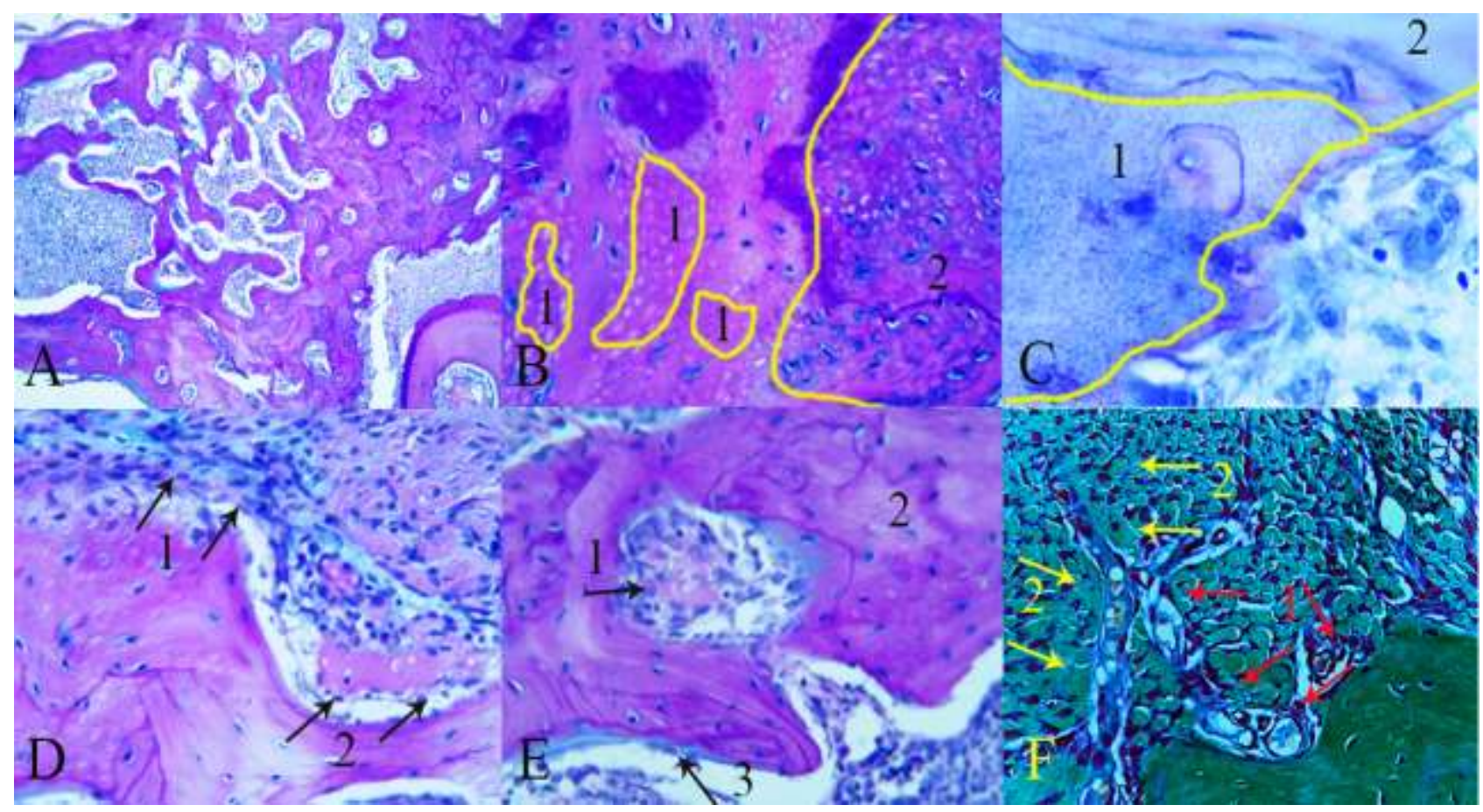

Fig.2 Microstructure of mandibles for animals that exposed to amino phosphonic impurity for 30 days and subsequent exposed to $5 \%$ solution of Trilon B for 30 days.

A. Structure of bone matrix: small medullar spaces. 2. Area of decoupled bone trabeculae. 3 Large medullar spaces. Hematoxylin and eosin staining. Magnification x 100; B.1. Areas of Ca-decreasing in the focal osteosclerosis at the places of former meshwork. 2. Areas of osteocytic osteolysis. Hematoxylin and eosin staining. Magnification x 400; C.1. Rarefication of bone matrix with fine-meshed structures. 2.

Lamellar bone without rarefication. Romanowsky-Giemsa staining. Magnification x 1000; D.1. Remodeling of collagenous-fibrous tissue in the region of marrow fibrosis. 2. Combined lysis of bone fragment; AB/PAS staining (pH 2.5). Magnification x 400; F. Remodeling of osteosclerosis area: 1 . Unconfined bone plates that covered meshwork. Fibro-reticular tissue grown between bone plates. 2 Newly formed vessels; Masson-Goldner staining. Magnification x 400. 
Нівелювання явищ асептичного остеонекрозу нижньощелепної кістки, викликаного прийомом наркотичних речовин, які містять амінофосфонові домішки, за допомогою Трилону Б в експерименті

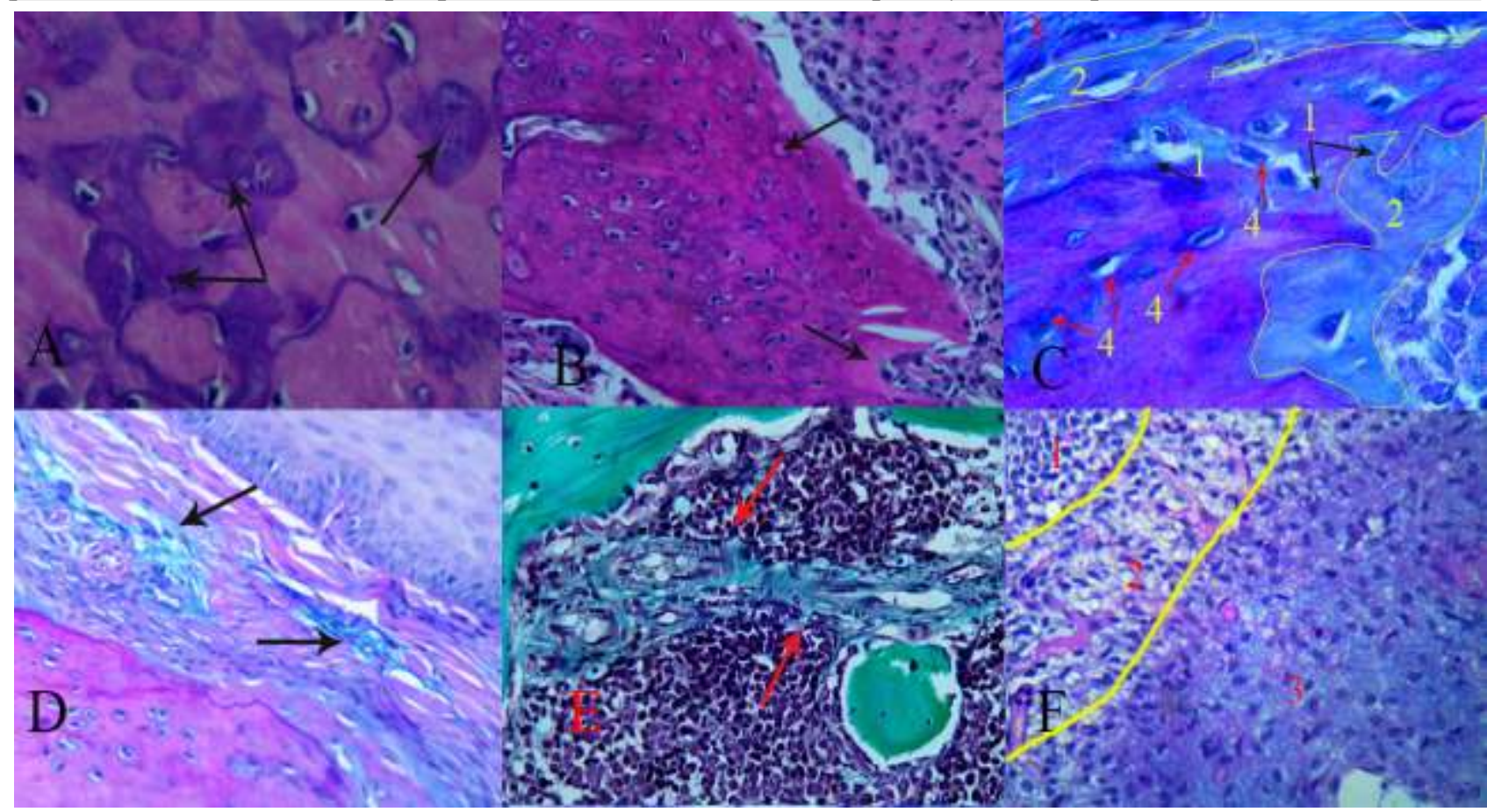

Fig.3. Microstructure of mandibles for animals that exposed to amino phosphonic impurity for 90 days and subsequent exposed to $5 \%$ solution of Trilon B for 30 days.

A. Area of defragmented basophil fragments deep to the bone matrix. Hematoxylin and eosin staining. Magnification x 1000; B. Metachromasia of bone matrix at the regions of intensive decalcification.

Hematoxylin and eosin staining. Magnification x 400; C.1. Peelin and lysis of inorganic micro fragments of bone matrix (non-cellular resorption). 2 Lysis of organic part of bone matrix (non-cellular resorption). 3. Collagenous-fibrous tissue in intertrabecular space. AB/PAS staining ( $p H$ 2.5). Magnification x 100. D.

Remodeling of collagenous-fibrous tissue at the regions of bone marrow fibrosis involution. AB/PAS

staining (pH 2.5). Magnification x 400. E. Marrow fibrosis involution, Masson-Goldner staining.

Magnification x 400. F. Restitution of histological and morphological structures in medullar cavity: 1 area of myelocytes colonization in bone marrow; 2 - transformed zone of forming reticular stroma; 3 - area of collagenous-fibrous tissue remodeling. AB/PAS staining (pH 2.5). Magnification x 400.

Violations of the mandible bone structure were detected for animals of the first and second groups. Exposure of non-narcotic impurity was 30 and 90 days. It was similar to our previous study [9]. Violations gradually ascended as the exposure time increased. This process was caused by calcifying as well as antitoxic and antiresorptive effects of the studied substance. These properties were evidenced as fibrinoid necrosis, abnormal accumulation of the mineral component and a small number of non-functional osteoclasts. Anoxia and displacement of bone remodeling towards the excessive osteocytic remodeling resulted. Processes of osteometaplasia that amplified osteoproliferative appositional growth of bone took place. That led to hyperostosis and the formation of non-functional fragile osseous osteosclerotic masses. These changes looked like ossifying osteitis (a form of aseptic osteonecrosis) [9, 18, 19] (Fig. 1. A, B, C; Tab. 1). There was no evidence of toxic vasculopathy and stromal vascular dystrophic disorders for the group of animals exposed to the impurity for 30 days and were treated with Trilon B chelation therapy. It could form a base for myelofibrotic and osteosclerotic lesions. Histoarchitecture of mandibular bone was heterogeneous. Small bone marrow cavities were surrounded by osteosclerosis areas and interspersed with areas of bone trabeculae as well as large bone marrow cavities. At the edge of the trabeculae, an intense basophilic rim was determined. Strips of bright blue color adjoined the bone marrow spaces. Bone reconstruction processes took place in areas of osteosclerotic changes. The intensity of osteocytic osteolysis increased. The area increased by 14\% (p<0,05), (Fig. 2. A, B, Tab. 1). Hypertrophied lacunae with increased osteocytes were detected among the cellular structures covered with lamellar bone. These lacunae had a sharp basophilic border around the edges and blue contents (alcian blue with a pH $2.5+$ Schiffreaction). The events of bone necrosis (the presence of three or more empty osteocytic lacunae in the field of vision, and lacunae with karyopyknotic and karyolitic osteocytes) were not determined. The lysis of septa between "nid d'abeilles" structures [9] was revealed, that's why unconfined bone plates were found in fibrous-reticular tissue. That respectively led to 
decreasing of spongy substance amount and osteosclerosis area by $15.3 \%$ and $15.4 \%$ ( $\mathrm{p}<0.05)$ respectively (Fig 2. C; Tab. 1). There were splits determined along the lines of cementation. Also, small bone fragmentation took place. Intensive basophilic staining (alcian blue staining with $\mathrm{pH} 2.5+$ Schiffreaction) of sclerotic bone marrow cavities and Haversian canals took place. Areas of bone rarefication with a fine-mesh structure were detected by Giemsa staining (Fig. 2. D.). Intensive basophilic edging was identified along the trabeculae borders. There were extended bright blue strips in certain areas. No cellular elements were found. These strips are situated along with bone marrow spaces. We regarded this phenomenon as the process of non-cellular resorption of the bone matrix [11]. The osteoclastic cell pool two times increased. The young cell forms were detected. Collagen-fibrous tissue near to the borders of trabeculae was enriched with cellular elements as osteoblasts, fibroblasts, macrophages, and eosinophils. Stellate cells with blue cytoplasm similar to fibroclasts were determined in areas of fibrous tissue dissociation. These areas became intensive blue color (alcian blue staining). The area of fibrous tissue that formed a basis for myelofibrosis was detected (Masson-Goldner staining). It decreased by $31 \%$ ( $p<0.05)$, compared to the same element in the first group. Stellate volume increased by 19\% (p<0.05) (Fig. 2. E, F; Tab. 1).

Treatment with Trilon B also demonstrated the absence of toxic-vasculopathy lesions, which could cause dystrophic changes for the group of animals exposed to studied impurity for 90 days. It was treated with chelation therapy for 30 days. The number of large and medium bone marrow cavities increased, and the remaining areas of the bone trabeculae helped to reveal a hyperostosis volume decreasing. Qualitative changes were confirmed with morphometric parameters. The volume of spongy substance decreased by $21 \%$ (p $<0.05)$, the area of osteosclerotic changes by $25 \%$ $(\mathrm{p}<0.05)$. Intensity for non-cellular bone remodeling increased, and attenuation of osteocytic osteolysis processes took place. Areas of osteocytic osteolysis decreased by $56 \%(\mathrm{p}<0.05)$. Multiple defragmentation sites of basophilic fragments took place deeply to the bone matrix (Fig. 3. A; Tab. 1). Metachromasia was detected - osteosclerotic plates covered the cellular structures, as well as the surrounding small bone marrow cavities and Haversian canals became pale pink color, in the absence of stippling, so we hypothesized the loss of the mineral carriers took place [11, 20]. Osseous micro fragments of the bone, defragmentation, and lysis of the revealed organic component were determined along the trabeculae borders. There was an intensive blue edging (alcian blue staining with $\mathrm{pH} 2.5$ + Schiff-reaction) (Fig. 3. C.) [11, 20, 21]. The intensity increased for connective tissue structural change/ remodeling in bone marrow cavities. A lot of newly formed vessels as well as dense cellular assemblies of fibroblasts, macrophages, defragmentation of collagenfibrous tissue were found in the areas of changed tissue. These zones became blue color (alcian blue staining with pH 2.5 + Schiff-reaction). Involution of collagenfibrous tissue was replaced by a reticular stroma with myeloid cells. The area of myelofibrosis (MassonGoldner staining) decreased by $31 \%$ ( $\mathrm{p}<0.05)$. Stellate volume increased by $16 \%$ (p<0.05) (Fig. 2. C, D, E, F; Tab. 1).

\section{DISCUSSION}

We considered variety properties of Trilon B such as decalcifying, angioprotective, antioxidative, and antiinflammatory activity $[22,23,24]$ It should be noted that morphological effects of the target substance, as we defined in the research, included pharmacological properties, were expressed in partial normalization for all revealed violations of the mandibular morphological structure throughout all the periods of study. Decalcifying properties were presented as activation of lytic processes by cellular and non-cellular mechanisms. The cellular mechanisms were most significant for animals at the third experimental group and visually determined by increased intensity of osteocytic osteolysis as well as restored activity and increased number of osteoclastic cells pool. Non-cellular mechanisms prevailed for animals in the fourth experimental group. It was expected due to the presence of wide-spread osteosclerotic cell-free zones.

We could talk about it because:

- An intense basophilic edging was identified along the trabeculae borders. There were extended strips of bright blue color in certain areas without cellular elements. These strips are situated near to bone marrow spaces (Fig. 2 D, E) [11, 20, 21].

- Multiple defragmentation areas of the calcified basophilic protein substance (Fig. $3 \mathrm{~A}$ ).

- Metachromasia was detected - osteosclerotic plates covered the cellular structures, as well as the surrounded small bone marrow cavities and Haversian canals were pale pink.

- Decurrence of stippling in these zones (alcian blue staining with $\mathrm{pH} 2.5+$ Schiff reaction) (Fig. 3 B.).

- Bone micro fragments were sloughed. The revealed organic component was defragmented and lysed. It had an intense blue edging of trabeculae borders (alcian blue staining with $\mathrm{pH} 2.5+$ Schiff-reaction) (Fig. $3 \mathrm{C}, \mathrm{D}$ ).

All morphological signs of the bone matrix lysis that we've described before were manifested as previously indicated in areas where cellular component has been lost. 
Нівелювання явищ асептичного остеонекрозу нижньощелепної кістки, викликаного прийомом наркотичних речовин, які містять амінофосфонові домішки, за допомогою Трилону Б в експерименті

Such positive signs of the regeneration process for a bone structural organization we could relate to several factors:

The interaction of the studied item and plasma calcium led to improve flow properties and acid-base imbalance to the acids. As a result, parathyroid hormone was activated. It triggered processes of cellular resorption $(22,23,24)$.

The investigated item could dissolve the salts of amino phosphonic acid. The source of it is an amino phosphonic impurity, contained in the mineral matrix, and resistant to enzymes secreted by cellular resorptive components [25].

Direct interaction of studied items and mineral components took place. Presence of a dark blue (basophilic) edge located along the trabeculae borders, with light blue stripes adjacent to the edge. These strips did not contain cellular elements in some areas near bone marrow cavities [11, 20,21].

Angioprotective, antioxidant and anti-inflammatory properties were presented as leveling of toxic vasculopathy effects and increased angiogenesis. It was expressed as:

- In areas of active resorption, there was a sclerosed, discomposed trabecular mass of fibroreticular tissue with a large number of plethoric vessels as well as pericytic infiltration with no signs of vascular wall damage (Fig. 2F).

- The processes of fibrous tissue involution that was manifested as the areas of dissolution of collagen fibers. These fibers contented stellate cells with a blue cytoplasm similar to fibroblasts (Fig. 3 D).

- Enrichment of involuted fibrous tissue, cellular elements due to osteoblasts, fibroblasts, macrophages, eosinophils (Fig. 3 E, F).

Thus, the 30-day administration of Trilon B after 30 and 90 daily exposures of the amino phosphonic impurity led to the normalization of bone remodeling processes and, consequently, decreased excessive and sclerosed bone substance. Involution of myelofibrotic processes in bone marrow cavities was a replacement of fibrotic zones with a reticular stroma and myeloid cells. Ample vascularization took place. For a short-term exposure of the amino phosphonic impurity (30 days), bone resorption has undergone a mixed mechanism with a cellular resorption predominance.

For a long-term exposure of the amino phosphonic impurity (90 days), bone resorption has undergone noncellular resorption. It was caused by a high density of bone matrix with avascular areas (osteosclerotic changes).

\section{CONCLUSIONS}

1. Trilon B at a dose of $250 \mathrm{mg} / \mathrm{kg}$ in laboratory white rats after 1 and 3 months of amino phosphonic impurity administrated intragastrically (at a dose of 63 $\mathrm{mg} / \mathrm{kg}$ ) normalized remodeling processes for mandible bone tissue. Activation of resorptive mechanisms led to leveling osteosclerosis changes, myelofibrotic zones involution, and restoration of microcirculation for the target organ.

2. Indirect effects were observed if Trilon B was used after 1 month of amino phosphonic impurity administration. Probably activation of resorption cellular mechanisms took place.

3. Normalization of remodeling processes was observed if Trilon B was used after 3 months of amino phosphonic impurity administration. The predominance of non-cellular resorption mechanisms induced by the direct drug effect was observed. Direct dissolution of the mineral and organic components took place.

\section{REFERENCES}

1. Виноградова, Н. Г.; Харитонова, М. П.; Львов, К. В. Медикаментозноассоциированные остеонекрозы челюсти - теории патогенеза, особенности клинической, рентгенологической картины: обзор литературы и собственные наблюдения. Уральский медицинский журнал. 2018, 4. с 38-48.

2. Медведев, Ю. А.; Басин, Е. М. Остеонекрозы костей лицевого скелета $\mathrm{y}$ лиц $\mathrm{c}$ наркотической зависимостью: клиника, диагностика, принципы лечения. Врач. 2012, 2, с 55-60.

3. Іваницька, О. С.; Рибалов, О. В. Сучасні уявлення про лікування токсичного некрозу щелеп у наркозалежних пацієнтів. Актуальні проблеми сучасної медицини: вісник української медичної стоматологічної академії. 2014, 1(45), с 133.

4. Басин, Е. М.; Кириллов, Ю. А.; Медведев, Ю. А.; Докина, Е. К. Клинико-морфологическая характеристика остеонекрозов лицевого черепа у лиц с наркотической зависимостью. Российский стоматологический журнал. 2015, 19(2), 14-17.

5. Rustemeye, J.; Melenberg, A.; Junker, K.; SariRieger, A. Osteonecrosis of the maxilla related to longstanding methamphetamine abuse: a possible new aspect in the etiology of osteonecrosis of the jaw. Oral and Maxillofacial Surgery 2014; 18 (2), 237-41. URL: http://doi.org/10.1007/s10006-014-0449-2

6. Скрипніков, А. М.; Напрєєнко, О. К.; Сонник, Г. T. Наркологія: навчально-методичний посібник / під заг. ред. д.мед.н. професора А. М. Скрипникова. Полтава, 2005; 90-91.

7. Bulletin on Narcotics: Science in Drug Control united 57. (1\&2), 65-78. FeliceO'Ryan. URL: https://www.unodc.org/pdf/research/Bulletin07/bulletin_on_ narcotics_2007.pdf

8. Mostovoy, S. O.; Shul'gin, V. F.; Maksimova, E. M.; Nauhatsky, I. A. et al. Mineralizing process and morphological structure of the femoral bone in rats under influence of aminophosphonates. J ExpIntegr Med. 2014, 4 (2), 81-84. URL: https:// doi.org/10.5455/jeim.260214.br.019 
9. Мостовой, С. О.; Пикалюк, В. С.; Шульгин, В Ф.; Пешков, М. В. Патоморфологические изменения нижних челюстей лабораторных белых крыс под воздействием аналога, фосфоросодержащего аутопатогеничного вещества. Крымский журнал экспериментальной и клинической медицины. 2017, 7 (2), 91-96.

10. Маланчук, В. А.; Бродецкий, И. С.; Остеомиелит челюстей у больных на фоне наркотической зависимости: учебное пособие. Национальная академия медицинских наук Украины: Киев, 2013, 252.

11. Мостовой, С. О.; Шульгин, В. Ф.; Пешков, М. В. Коррекция с помощью хелатообразующих веществ остеосклеротических изменений в нижнечелюстной кости крыс, вызванных приёмом бисфосфонатов. Цитология. 2018, 60 (6), 476-482.

12. Рыболовлев, Ю. Р.; Рыболовлев, Р. С. Дозирование веществ для млекопитающих по константе биологической активности. Доклады АН СССР.1979, 247 (6), 1513-1516.

13. European convention for the protection of vertebrate animals used for experimental and other scientific purpose: Council of Europe. 18.03.1986. Strasbourg, 1986; 52.

14. Пешков, M. В. Декальцинация в гистологической лабораторной технике. Архив патологии. 2012, 6, 44-46.

15. Buesa, R. J.; Peshkov, M. V. Histology without xylene. Ann. Diagn. Pathol. 2009, 13, 246-256. URL: https://doi.org/10.1016/j.anndiagpath.2008.12.005

16. Dempster, D. W.; Compston, J. E.; Drezner, M. K.; Glorieux, F. H. et al. Standardized Nomenclature, Symbols, and Units for Bone Histomorphometry: A 2012 Update of the Report of the ASBMR Histomorphometry Nomenclature Committee. Journal of Bone and Mineral Research. 2013, 28 (1), 1-16. URL: https://doi.org/ 10.1002/jbmr.1805

17. Vesterby, A. Star volume in bone research. A histo- morphometric analysis of trabecular bone structure usingvertical sections Anat. Rec.1993, 235 (2), 325-334. URL: https://doi.org/10.1002/ar.1092350217

18. Green, T. L.; Walton, R. E.; Clark, J. M.; \& Maixner, D. (2013). Histologic Examination of Condensing Osteitis in Cadaver Specimens. Journal of Endodontics; 39 (8), 977-979. DOI: 10.1016/j.joen.2013.02.002

19. Marx, RE. Pamidronate (Aredia) and zoledronate (Zometa) induced avascular necrosis of the jaws: a growing epidemic. J Oral Maxillofac. 2003, 61, 1115-1117. URL: https://doi.org/10.1016/S0278-2391(03)00720-1

20. Русаков, А. В. Введение в физиологию и патологию костной ткани. В Многотомное руководство по патологической анатомии. Медгиз: Москва, 1959.

21. Серов, В. В.; Шехтер, А. Б. Соединительная ткань. Функциональная морфология и общая патология. Медицина: Москва, 1981.

22. Goossens, W.; Van Duppen V.; Verwilghen, R. L. K2- or K3-EDTA: the anticoagulant of choice in routine haematology. Clin. Lab. Haematol. 1991; 13, 291-295. URL: https://doi.org/10.1111/j.1365-2257.1991.tb00284.x

23. Guldager, B.; Brixen, K. T.; Jørgensen, S. J.; Nielsen, H. K. et al. Effects of intravenous EDTA treatment on serum parathyroid hormone (1-84) and biochemical markers of bone turnover. Dan. Med. Bull. 1993, 40 (5), 627630. URL: https://doi.org/10.1186/1471-2261-5-32

24. Yang Lei, Aditi Sinha, Naren Vyavahare. Efficacy of reversal of aortic calcification by chelating agents. Calcif. Tissue Int. 2013, 93 (5), 426-435. URL: https://doi.org/10.1007/s00223-013-9780-0

25. Nancollas, G. H., Tang, R.; Phipps, R. J.; Henneman, Z.; Gulde, S.; Mangood, W.Wu.A, Russell, R.G.G., Ebetino, F. H. Novel insights into actions of bisphosphonates on bone: Differences in interactions with hydroxyapatite Bone. 2006, 38, 617-627. URL: https://doi.org/10.1016/j.bone.2005.05.003 